\title{
DAMPAK PENERAPAN PSAK 4 (REVISI 1994) DAN PSAK 4 (REVISI 2009) TERHADAP LAPORAN KEUANGAN KONSOLIDASIAN PERUSAHAAN
}

\author{
(Studi kasus pada PT Tempo Scan Pacific, Tbk. Jakarta) \\ Oleh: Dea Sugita \\ deasugitadea@gmail.com
}

\begin{abstract}
The purpose of this study was to determine how the impact of the adoption of SFAS 4 (Revised 1994) and SFAS 4 (Revised 2009) on the consolidated financial statements of PT Tempo Scan Pacific Tbk and its subsidiaries in 2010 and 2012, whether it has been overall implemented or not in the company, In addition, this study also aims to determine how the impact of the difference due to the change due to the convergence of IFRS in the consolidated financial statements in 2010 that is guided by SFAS 4 (Revised 1994) and in 2012 guided by SFAS 4 (Revised 2009) regarding reports the consolidated financial companies, whether these changes benefit the company or even vice versa.

The method used in this research is descriptive qualitative method. This research method is done by thoroughly describe or depict the views of the notes to the consolidated financial statements where in the notes to the consolidated financial statements are included discussion of the basis and principles for presenting consolidated with all explanations related to the consolidation were applied in the consolidated financial statements of PT Tempo Scan Pacific Tbk, as well as analyze the impact of differences in the consolidated statement of financial position, consolidated statement of comprehensive income, consolidated statement of changes in equity and cash flows in 2010 to 2012 which is part of the consolidated financial statements of the company. Where these data the authors obtained from secondary data source that the official website of Indonesia Stock Exchange with the year 2010, based on the preparation of SFAS 4 (Revised 1994) and in 2012 guided by SFAS 4 (Revised 2009). The results showed that PT Tempo Scan Pacific Tbk in the preparation and presentation of consolidated financial statements in 2010 and in 2012 has been broadly guided by SFAS 4 (Revised 1994) and SFAS 4 (Revised 2009), but there are still some posts that have not been implemented and there are also some posts that are not disclosed clearly as in the discussion. And based on the results of the analysis of that difference due to changes resulting from the convergence of IFRS on the consolidated financial statements of the company has been mostly profitable companies.
\end{abstract}

Keywords: SFAS 4, Presentation of Financial Statements The consolidated

\section{PENDAHULUAN}

Di dalam dunia bisnis, penggabungan usaha merupakan cara yang sangat efektif dalam memperluas usaha. Penggabungan usaha merupakan titik awal dimulainya kegiatan penyusunan laporan konsolidasian. Laporan keuangan konsolidasian yang disajikan oleh seluruh perusahaan di Indonesia yang memiliki anak perusahaan baik di dalam negeri maupun di luar negeri harus disajikan sesuai dengan standar akuntansi yang berlaku secara umum. 
Standar-standar akuntansi pada setiap negara tidaklah sama. Hal ini diakibatkan dengan kondisi ekonomi di setiap negara yang berbeda. Dan hal tersebut mempersulit pengguna laporan keuangan dalam memahami isi laporan keuangan. Maka dari itu International Accounting Standards Board (IASB) membentuk adanya standar-standar akuntansi international yang dapat diterapkan oleh setiap negara yaitu International Financial Reporting Standards (IFRS). Untuk menerapkan International Financial Reporting Standards (IFRS) maka setiap negara khususnya Indonesia perlu melakukan konvergensi dari standar akuntansi lokal masing-masing negara ke dalam IFRS.

Berdasarkan hasil konvergensi PSAK ke dalam IFRS maka terjadi perubahan-perubahan terhadap kebijakan penyusunan laporan keuangan konsolidasian di Indonesia, salah satunya adalah pada PSAK 4. Dalam menentukan objek penelitian, penulis melihat bahwa dengan adanya penerapan yang baru terhadap perlakuan standar-standar akuntansi yang telah dikonvergensi dari IAS 27 : Consolidated and Separate Financial Statements, terutama PSAK 4 (revisi 2009) yang berisi tentang penyusunan dan penyajian laporan keuangan konsolidasian untuk sekelompok entitas yang berada dalam pengendalian suatu entitas induk pada lembaga keuangan dapat memberikan pengaruh ke dalam penyusunan laporan keuangan konsolidasian. Namun pengaruh dari perubahan tersebut belum tentu menguntungkan bagi semua pihak pengguna maupun pembaca laporan keuangan, oleh karena itu penulis tertarik untuk menganalisis dampak dari perubahan PSAK 4 (revisi 1994) sebelum IFRS dan PSAK 4 (revisi 2009) sesudah IFRS tersebut agar dapat melihat apakah perubahan yang terjadi dalam PSAK 4 tersebut menguntungkan atau tidak bagi perusahaan.

Dalam penelitian ini penulis fokus terhadap penyajian dan penyusunan laporan keuangan konsolidasian dan tidak membahas secara detail untuk laporan keuangan tersendiri, walaupun PSAK 4 (revisi 2009) mengatur keduanya. Penulis belum menggunakan PSAK 65 : Laporan Keuangan Konsolidasian sebagai pengganti PSAK 4 (revisi 2009) dalam revisi 2013 yang efektif pada tanggal 1 Januari tahun 2015, karena laporan keuangan perusahaan yang digunakan dalam penelitian ini adalah laporan keuangan konsolidasian tahun 2010 yang berpedoman pada PSAK 4 (revisi 1994) dan tahun 2012 yang berpedoman pada PSAK 4 (revisi 2009) yang belum menggunakan PSAK tersebut.

Berdasarkan gambaran dan uraian di atas, maka penulis tertarik melakukan analisis untuk mengetahui bagaimana dampak dari penerapan PSAK 4 (revisi 1994) dan PSAK 4 (revisi 2009) terhadap laporan keuangan konsolidasian serta pengaruhnya bagi perusahaan. Oleh karena itu penulis mengambil penelitian dengan judul : " DAMPAK PENERAPAN PSAK 4 (REVISI 1994) DAN PSAK 4 (REVISI 2009) TERHADAP LAPORAN KEUANGAN KONSOLIDASIAN PERUSAHAAN."

\section{Identifikasi Masalah}

1. Bagaimana penerapan PSAK 4 (revisi 1994) dalam penyajian Laporan Keuangan Konsolidasian PT. Tempo Scan Pacific Tbk tahun 2010 dan penerapan PSAK 4 (revisi 2009) dalam penyajian Laporan Keuangan Konsolidasian PT. Tempo Scan Pacific Tbk tahun 2012 ?

2. Bagaimana dampak penerapan PSAK 4 (revisi 1994) sebelum IFRS dan PSAK 4 (revisi 2009) sesudah IFRS terhadap Laporan Keuangan Konsolidasian PT. Tempo Scan Pacific Tbk? 


\section{Maksud dan Tujuan Penelitian}

Maksud dan tujuan penelitian ini adalah untuk dapat mengetahui dampak serta pengaruh dari adanya penerapan PSAK 4 (revisi 1994) sebelum IFRS dan PSAK 4 (revisi 2009) sesudah IFRS terhadap Laporan Keuangan Konsolidasian PT. Tempo Scan Pacific Tbk.

\section{KERANGKA PEMIKIRAN TEORITIS}

\section{Pernyataan Standar Akuntansi Keuangan (PSAK)}

Standar Akuntansi Keuangan atau PSAK adalah suatu pedoman dalam melakukan praktek akuntansi dimana uraian materi didalamnya mencakup hampir semua aspek yang berkaitan dengan akuntansi, yang dalam penyusunannya melibatkan sekumpulan orang dengan kemampuan dalam bidang akuntansi yang tergabung dalam suatu lembaga yang dinamakan Ikatan Akuntan Indonesia (IAI). Dengan kata lain Pernyataan Standar Akuntansi Keuangan atau PSAK adalah buku petunjuk bagi yang ada hubungannya dengan akuntansi. Standar Akuntansi Keuangan (SAK) mencakup konvensi, peraturan dan prosedur yang sudah disusun dan disahkan oleh lembaga resmi (standard setting body) pada saat tertentu.

Pernyataan diatas memberikan gambaran bahwa Pernyataan Standar Akuntansi Keuangan (PSAK) berisi "tata cara penyusunan laporan keuangan" yang selalu mengacu pada teori yang berlaku, atau dengan kata lain didasarkan pada kondisi yang sedang berlangsung.

(PSAK) bukan merupakan suatu kemutlakan bagi setiap perusahaan dalam membuat laporan keuangan. Namun paling tidak dapat memastikan bahwa penempatan unsur-unsur atau elemen data ekonomi harus ditetapkan pada posisi yang tepat agar semua data ekonomi dapat tersaji dengan baik, sehingga dapat memudahkan bagi pihak-pihak yang berkepentingan dalam menginterpretasikan dan mengevaluasi suatu laporan keuangan guna mengambil keputusan ekonomi yang baik bagi tiap-tiap pihak.

\section{PSAK 4 (revisi 1994) dan PSAK 4 (revisi 2009)}

PSAK (revisi 2009): Laporan Keuangan Konsolidasi dan Laporan Keuangan Tersendiri mengadopsi seluruh pengaturan dalam IAS 27 (2009): Consolidated and Separate Financial Statements, kecuali untuk beberapa hal. Menurut PSAK 4 (revisi 2009) pengendalian dianggap ada ketika entitas induk memiliki secara langsung atau tidak langsung melalui entitas anak lebih dari setengah kekuasaan suara suatu entitas, kecuali dalam keadaan yang jarang dapat ditunjukan secara jelas bahwa kepemilikan tersebut tidak diikuti dengan pengendalian.

Dalam PSAK 4 (revisi 2009) dalam paragraf 15 menyatakan bahwa Dalam menyusun laporan keuangan konsolidasian, entitas menggabungkan laporan keuangan entitas induk dan entitas anak satu per satu dengan menjumlahkan pos-pos sejenis dari aset, liabilitas, ekuitas, penghasilan, dan beban. Kepentingan nonpengendali disajikan di ekuitas dalam laporan posisi keuangan konsolidasian, terpisah dari ekuitas pemilik entitas induk. Laba rugi dan setiap komponen pendapatan komprehensif lain diatribusikan pada pemilik entitas induk dan pada kepentingan nonpengendali. Seluruh laba rugi komprehensif diatribusikan pada pemilik entitas induk dan pada kepentingan nonpengendali bahkan jika hal ini mengakibatkan kepentingan nonpengendali mempunyai saldo defisit. 
Pada saat kehilangan pengendalian atas entitas anak, setiap sisa investasi pada entitas anak terdahulu dan setiap jumlah terutang oleh atau kepada entitas anak terdahulu dicatat sesuai dengan SAK lain sejak tanggal hilangnya pengendalian. Menurut Eng Juan, Tri Wahyuni (2012:604) dalam bukunya Panduan Praktis Standar Akuntansi Keuangan menjelaskan bahwa "Dalam laporan keuangan tersendiri induk perusahaan, akuntansi untuk investasi di anak perusahaan bergantung pada apakah anak perusahaan tersebut disertakan dalam laporan keuangan konsolidasi."

Menurut PSAK 4 (revisi 1994) dalam bagian pengungkapannya pada paragraf 17 menyatakan bahwa agar para pengguna laporan keuangan konsolidasi dapat memahami hubungan antara perusahaan-perusahaan dalam satu grup, maka pengungkapan atas hal-hal berikut harus dilakukan :

a. Daftar anak perusahaan (yang signifikan) yang antara lain mencakup : nama, tempat, kedudukan, persentase pemilikan, dan persentase hak suara (apabila berbeda dengan persentase pemilikan).

b. Alasan untuk tidak mengkonsolidasikan suatu anak perusahaan.

c. Sifat hubungan antara induk perusahaan dan anak perusahaan yang menyebabkan induk perusahaan dapat melakukan pengendalian terhadap anak perusahaan meskipun hak suara induk perusahaan, baik langsung maupun tidak langsung, 50\% atau kurang.

\section{Pengertian dan Tujuan Laporan Keuangan Konsolidasian}

Menurut Richard E. Beaker, Valdean C. Lembke et al (2009:85) dalam bukunya Advance Financial Accounting:

"Consolidated financial statement present the financial position and result of operation for a parent (controlling entity) and one or more subsidiary (controled entities) as if all the individual entities actually were a single company or entity. Consolidation if require when a corporation owns a majority of another corporations outstanding common stock."

Menurut Beams (2007:12) dalam bukunya yang berjudul Akuntansi Lanjutan menjelaskan bahwa "Laporan keuangan konsolidasi adalah laporan yang bertujuan untuk menyajikan, terutama untuk kepentingan pemegang saham dan kreditur induk perusahaan, hasil operasi dan posisi keuangan induk perusahaan dan anak, seolah-olah kelompok perusahaan tersebut adalah perusahaan tunggal dengan satu atau lebih cabang atau divisi".

\section{Kepentingan Nonpengendali}

Menurut Beams (2007:89) menjelaskan bahwa "Pada dasarnya, klasifikasi kepemilikan pemegang saham minoritas sebagai kewajiban tidak konsisten karena hak minoritas mencerminkan investasi ekuitas pada aktiva bersih konsolidasi oleh pemegang saham di luar struktur afiliasi."

Menurut Baker (2010:98), induk perusahaan tidak selalu memiliki $100 \%$ saham biasa anak perusahaan yang beredar. Induk perusahaan dapat memiliki kurang dari $100 \%$ saham suatu perusahaan dalam penggabungan usaha, atau pada awalnya memiliki $100 \%$ tapi kemudian dijual atau diberikan beberapa lembar ke pihak lain. Dalam mengonsolidasi anak perusahaan, induk perusahaan hanya perlu mempunyai kepemilikan pengendali. Saham lain dari anak perusahaan yang tidak dimiliki induk perusahaan disebut pemegang saham "nonpengendali" atau "minoritas". Klaim dari pemegang saham tersebut atas laba dan aset bersih anak perusahaan disebut kepemilikan nonpengendali (noncontrolling interest) atau kepemilikan monoritas (minority interest). 


\section{KERANGKA PEMIKIRAN KONSEPTUAL}

Berikut merupakan kerangka pemikiran konseptual dalam penelitian ini :

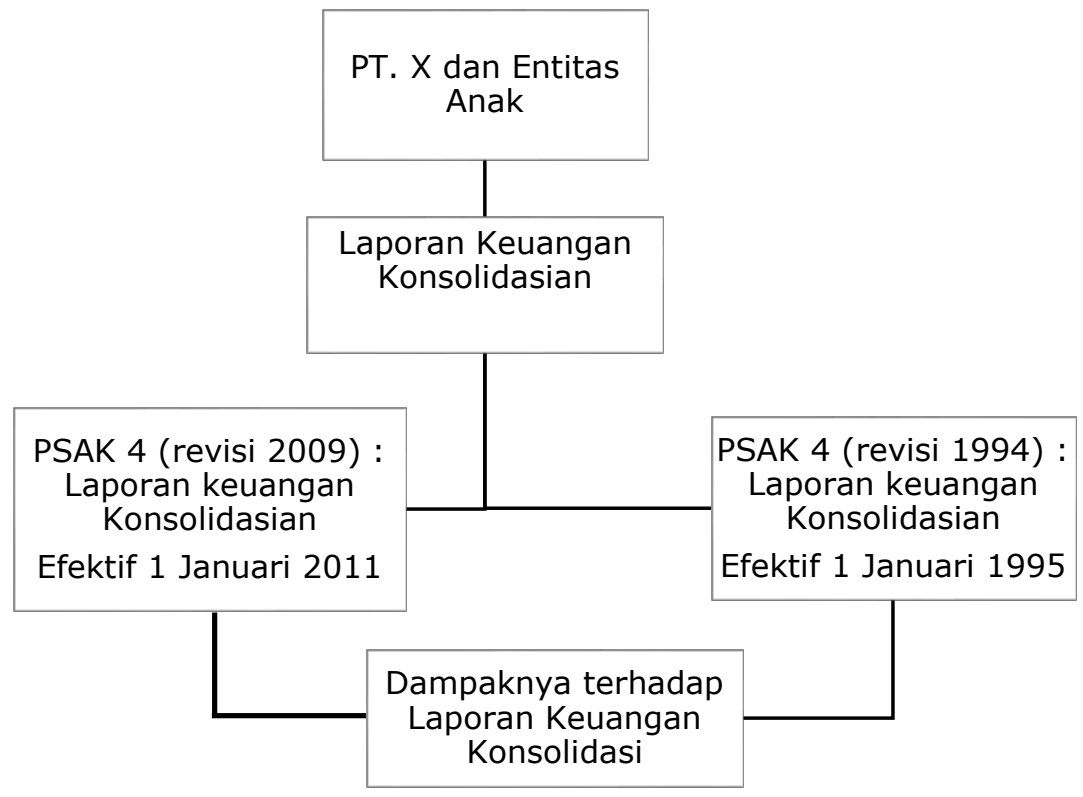

Gambar 1 Kerangka Pemikiran Konseptual

\section{METODE PENELITIAN}

Metode penelitian yang digunakan dalam penyusunan skripsi ini adalah dengan menggunakan metode deskriptif dimana penulis akan menganalisis dan kemudian menjelaskan (explanatory research) mengenai bagaimana penerapan PSAK 4 (revisi 1994) dalam laporan keuangan konsolidasian PT. Tempo Scan Pacific Tbk tahun 2010 dan penerapan PSAK 4 (revisi 2009) dalam laporan keuangan konsolidasian PT. Tempo Scan Pacific Tbk tahun 2012, serta menganalisis dampak dari penerapan tersebut bagi perusahaan dengan melihat perubahan yang terjadi dalam kedua laporan keuangan konsolidasian yang didasarnya pada PSAK 4 tersebut.

\section{Operasionalisasi Variabel}

Tabel 1 Operasionalisasi Variabel

\begin{tabular}{|l|l|}
\hline \multicolumn{1}{|c|}{ Variabel/Sub variabel } & \multicolumn{1}{c|}{ Indikator } \\
\hline $\begin{array}{l}\text { PSAK 4 (revisi 2009) Laporan } \\
\text { Keuangan Konsolidasian }\end{array}$ & $\begin{array}{l}\text { Penyajian } \\
\text { Ruang Lingkup } \\
\text { Prosedur } 1 \text { Januari 2011 } \\
\text { Kehilangan Pengendalian } \\
\text { Pengungkapan }\end{array}$ \\
\hline $\begin{array}{l}\text { PSAK 4 (revisi 1994) Laporan } \\
\text { Keuangan Konsolidasian }\end{array}$ & $\begin{array}{l}\text { Ruang Lingkup } \\
\text { Efektif 1 Januari 1995 }\end{array}$ \\
\hline $\begin{array}{l}\text { Laporan Keuangan } \\
\text { Konsolidasian Perusahaan }\end{array}$ & $\begin{array}{l}\text { Pengungkapan } \\
\text { Labisi keuangan Konsolidasian }\end{array}$ \\
& $\begin{array}{l}\text { Perubahan Ekuitas Konsolidasian } \\
\text { Arus Kas Konsolidasian } \\
\text { Catatan Atas Laporan Keuangan Konsolidasian }\end{array}$ \\
\hline
\end{tabular}

\section{Jenis dan Sumber Data}


Data yang digunakan oleh penulis adalah data sekunder. Data sekunder yang diperoleh penulis merupakan data yang telah tersedia dari sumbernya yaitu www.idx.co.id yang merupakan situs resmi Bursa Efek Indonesia. Perusahaan yang digunakan sebagai data penelitian ini adalah salah satu perusahaan manufaktur yang terdaftar dalam Bursa Efek Indonesia (BEI) yaitu PT. Tempo scan Pacific Tbk dengan tahun pelaporan tahun 2010 yang berpedoman pada PSAK 4 (revisi 1994) dan tahun 2012 yang berpedoman pada PSAK 4 (revisi 2009). Penulis mengambil dua tahun pelaporan tersebut karena PSAK 4 revisi 2009 efektif pada tahun 2011 sehingga penulis membutuhkan tahun sebelum PSAK 4 tersebut efektif yaitu tahun 2010 dan sesudah PSAK tersebut efektif yaitu tahun 2012 untuk dapat melihat perbedaan antara keduanya.

\section{Metode Analisis}

Metode analisis yang digunakan penulis dalam penelitian ini adalah metode analisis kualitatif melalui prosedur deskriptif, di mana penulis melakukan penelitian dengan studi pustaka yaitu dengan mencari kebijakan serta teori yang berkaitan dengan penyusunan laporan keuangan konsolidasian pada buku-buku serta website terkait. Pada dasarnya, metode pengumpulan data dalam penelitian kualitatif sekaligus juga metode analisis data, sehingga proses pengumpulan data juga sekaligus adalah proses analisis data (Setiawan, 2013, 2015).

\section{HASIL DAN PEMBAHASAN}

\section{Penerapan PSAK 4 (revisi 1994) dan PSAK 4 (revisi 2009) Dalam Penyajian Laporan Keuangan Konsolidasian PT. Tempo Scan Pacific Tbk Tahun 2010 dan 2012}

Secara keseluruhan laporan keuangan konsolidasian PT Tempo scan Pacific Tbk tahun 2010 yang sesuai dengan PSAK 4 (revisi 1994) dan tahun 2012 yang sesuai dengan PSAK 4 (revisi 2009) sudah disajikan dengan benar dan diungkapkan secara jelas kecuali untuk beberapa bagian yang belum diungkapkan perusahaan karena tidak sesuai dengan kebijakan perusahaan itu sendiri. Karena tidak semua poin di dalam PSAK 4 dapat diterapkan terhadap semua perusahaan. Hal tersebut harus disesuaikan dengan kebijakan masing-masing perusahaan yang bersangkutan.

\section{Dampak Penerapan PSAK 4 (revisi 1994) Sebelum IFRS dan PSAK 4 (revisi 2009) Sesudah IFRS Terhadap Laporan Keuangan Konsolidasian PT. Tempo Scan Pacific Tbk}

Di dalam laporan keuangan konsolidasian yang disajikan oleh PT Tempo Scan Pacific Tbk pada tahun 2010 dan tahun 2012 yang penulis peroleh dari www.idx.co.id terlihat ada perbedaan dalam penyajian maupun pengungkapan laporan keuangan konsolidasian. Analisis perbedaan tersebut penulis lakukan guna melihat dampak dari adanya perubahan penerapan PSAK 4 (revisi 2009) yang sebelumnya menggunakan PSAK 4 (revisi 1994) tersebut terhadap laporan keuangan konsolidasian PT. Tempo Scan Pacific Tbk, apakah memberi dampak positif dan menguntungkan perusahaan atau malah sebaliknya. Karena belum tentu semua persahaan akan mendapatkan dampak yang baik dari adanya perubahan akibat konvergensi IFRS tersebut, hal ini harus disesuaikan dengan kondisi perusahaan itu sendiri. 
Berikut ini merupakan analisis perbedaan-perbedaan tersebut secara rinci yang disajikan dalam tabel dari ke empat laporan keuangan konsolidasian :

Tabel 2

PT TEMPO SCAN PACIFIC TbK DAN ANAK PERUSAHAAN LAPORAN POSISI KEUANGAN KONSOLIDASIAN

31 DESEMBER 2010 DAN 2012

(Disajikan dalam Rupiah, kecuali dinyatakan lain)

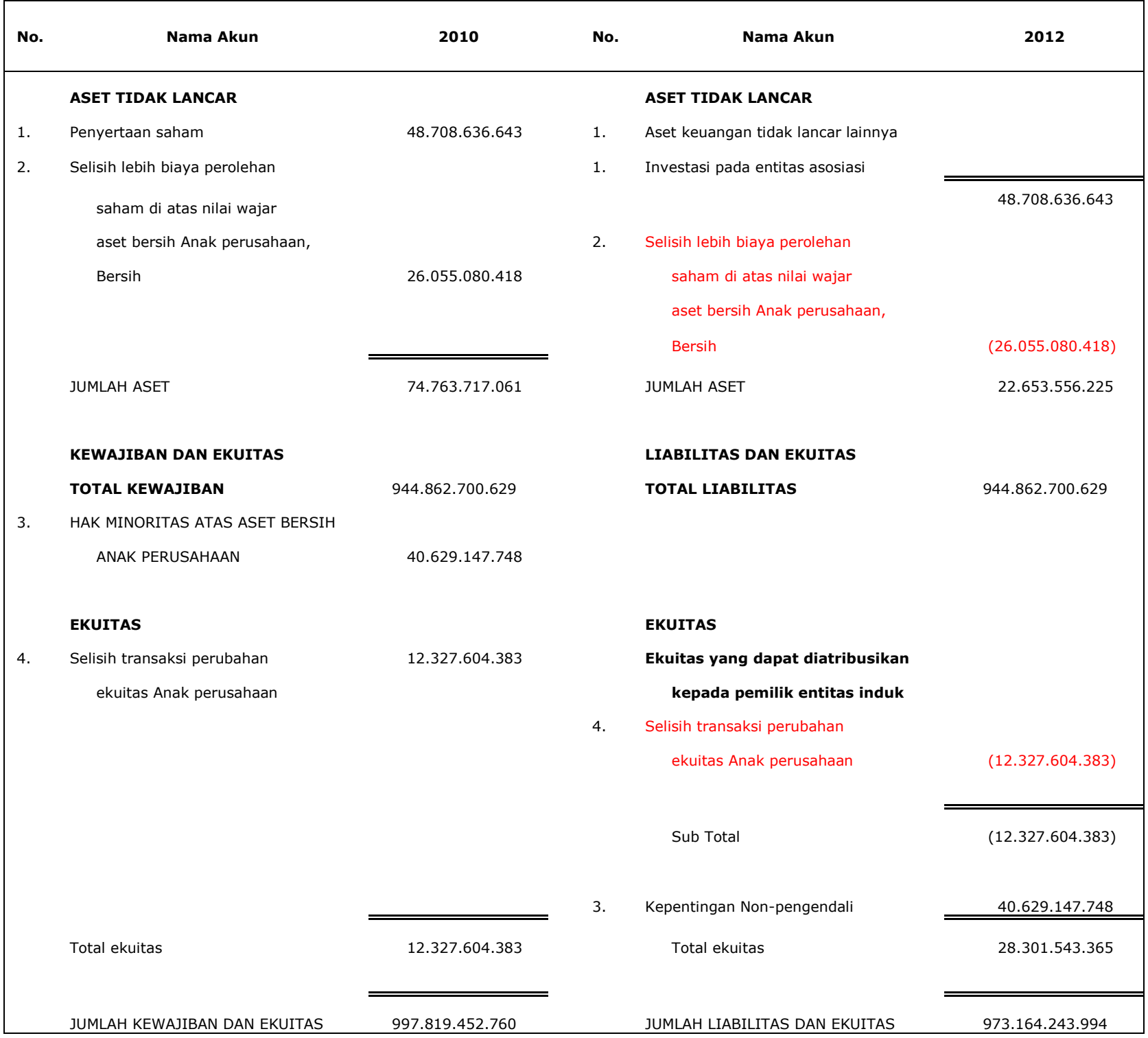


Akun selisih lebih biaya perolehan saham di atas nilai wajar aset bersih anak perusahaan yang terdapat dalam laporan posisi keuangan konsolidasian tahun 2010 di sisi aset tidak lancar, tidak terdapat dalam laporan posisi keuangan konsolidasian tahun 2012. Pada tahun 2010 akun selisih lebih biaya perolehan saham di atas nilai wajar aset bersih anak perusahaan tersebut menambah total aset tidak lancar yang otomatis menambah total aset, apabila dalam tahun 2012 akun tersebut tidak ada berarti total dari aset tahun 2012 berkurang. Berkurangkan total aset akan berdampak kepada Return of Investment (ROI) yang memiliki rumus perhitungan :

$$
\text { Return of Investment }(R O I)=\frac{E A T}{\text { Jumlah aset }} \times 100 \%
$$

Jika total aset berkurang atau lebih rendah, maka akan semakin kecil pembagi dalam rumus diatas yang menyebabkan persentasenya akan semakin tinggi. Semakin tinggi nilai persentase ROI ini adalah semakin baik bagi perusahaan, karena ROI yang semakin meningkat menunjukkan kinerja perusahaan yang semakin baik dan para pemegang saham akan memperoleh keuntungan dari dividen yang diterima yang semakin meningkat. Menurunnya total aset akan berdampak pula pada Total Debt to Assets Ratio (DAR) atau rasio untuk mengukur kemampuan perusahaan dalam menjamin hutanghutangnya dengan sejumlah aktiva yang dimilikinya. Debt to Assets Ratio dapat dihitung dengan rumus :

$$
\text { Dept to Assets }=\frac{\text { Total hutang }}{\text { Total aset }} \times 100 \%
$$

Sama halnya dengan ROI diatas, jika total aset menurun maka pembagi dalam rumus diatas akan semakin kecil yang menyebabkan hasi persentasenya semakin tinggi. Semakin tinggi persentase DAR maka akan semakin besar pula jumlah aset yang dibiayai hutang, semakin tinggi resiko perusahaan untuk menyelesaikan kewajiban jangka panjang, dan semakin tinggi beban bungan hutang yang harus ditanggung perusahaan. Menurunnya total aset juga akan berpengaruh pada semakin meningkatnya persentase dari TATO (Total Asset Turn Over) dimana sama seperti ROI dan Total Dept To Assets rumus dari TATO menjadikan total aset sebagai pembagi.

$$
\text { Total Assets Turn Over Ratio }=\frac{\text { Penjualan }}{\text { Total Aset }} \times 100 \%
$$

TATO penting bagi para kreditur dan pemilik perusahaan, dan lebih penting lagi bagi manajemen perusahaan, karena hal ini akan menunjukkan efisien tidaknya penggunaan seluruh aset didalam perusahaan. Penelitian ini juga menyimpulkan bahwa semakin tinggi persentase TATO maka semakin tinggi pula perubahan labanya. Pada laporan keuangan konsolidasian tahun 2010 yang berpedoman pada PSAK 4 (revisi 1994) menggunakan akun hak minoritas (minority interest) yang disajikan di antara kewajiban dan ekuitas dalam laporan posisi keuangan konsolidasian. Bagian proporsional minoritas tersebut dalam aset bersih disajikan dalam akun " Hak minoritas atas aset bersih anak perusahaan" yang menjadi penambah pada sisi kewajiban dan ekuitas perusahaan. Pada laporan keuangan konsolidasian tahun 2012 yang 
berpedoman pada PSAK 4 (revisi 2009), akun hak minoritas dihapuskan dan diganti dengan akun kepentingan nonpengendali (non controlling interest) yang disajikan sebagai bagian dari ekuitas dalam laporan posisi keuangan konsolidasian, terpisah dari ekuitas pemilik entitas induk. Perubahan tersebut akan berpengaruh pada semakin besarnya saldo ekuitas pada laporan posisi keuangan konsolidasian tahun 2012 sesudah IFRS yang berpedoman pada PSAK 4 (revisi 2009) karena akun hak minoritas atas aset bersih yang semula berada antara kewajiban dan ekuitas kemudian menjadi bagian dari ekuitas yang terpisah dari ekuitas pemilik entitas induk.

Meningkatnya totas ekuitas akan berdampak pada Return on Equity miliki rumus perhitungan :

$$
\text { Return on Equity }(R O E)=\frac{E A T}{\text { Jumlah Equity }} \times 100 \%
$$

Jika total ekuitas meningkat maka pembagi dalam rumus diatas akan semakin besar dan membuat hasil persentase semakin kecil. Jadi dapat diambil kesimpulan bahwa apabila persentase ROE semakin menurun maka akan berdampak tidak baik, karena perusahaan dianggap tidak efektif dalam menggunakan ekuitasnya untuk menghasilkan laba.

- Akun selisih transaksi perubahan ekuitas anak perusahaan timbul dari adanya PSAK 40 : Akuntansi Perubahan Ekuitas Anak Perusahaan/Perusahaan Asosiasi. Di dalam laporan posisi keuangan konsolidasian PT. Tempo Scan Pacific Tbk tahun 2012 tidak menyajikan akun selisih transaksi perubahan ekuitas anak perusahaan tersebut karena PSAK 40 : Akuntansi Perubahan Ekuitas Anak Perusahaan/Perusahaan Asosiasi telah dicabut mulai tanggal 1 Januari 2011 dan digantikan dengan PSAK 15 : Investasi pada Entitas Asosiasi.

Dampak yang dapat terlihat dari laporan posisi keuangan konsolidasiannya adalah akun selisih transaksi perubahan ekuitas yang menambah total dari ekuitas akan hilang, dan akan membuat sisi ekuitas d tahun 2012 menjadi menurun karena tidak adanya akun tersebut. Menurunnya total dari ekuitas akan berdampak pada menurunnya persentase Return on Equity (ROE) seperti yang dijelaskan pada poin tiga di atas, yang kan berdampak tidak baik bagi perusahaan.

- Di dalam laporan laba rugi konsolidasian tahun 2010 yang berpedoman pada PSAK 4 (revisi 1994) menyajikan akun amortisasi selisih lebih biaya perolehan saham di atas nilai wajar aset bersih anak perusahaan yang disajikan sebagai pengurang dari total pendapatan yang diperoleh, akun ini merupakan pengurang dari saldo akun selisih lebih biaya perolehan saham di atas nilai wajar aset bersih anak perusahaan yang disajikan karena laporan keuangan konsolidasiannya menggunakan metode ekuitas seperti yang sudah dibahas dalam perbedaan pada akun selisih lebih biaya perolehan saham di atas nilai wajar aset bersih anak perusahaan.

Sedangkan di laporan laba rugi komprehensif tahun 2012 yang berpedoman pada PSAK 4 (revisi 2009) tidak menyajikan akun tersebut, karena laporan keuangan konsolidasian disajikan dengan metode biaya seperti yang sudah dijelaskan sebelumnya. Tidak disajikannya akun tersebut akan berdampak pada meningkatnya total pendapatan dan meningkatnya pula total laba yang diperoleh karena akun yang sebelumnya ada sebagai pengurang total pendapatan menjadi hilang. 
- Dalam laporan laba rugi konsolidasian tahun 2010 yang berpedoman pada PSAK 4 (revisi 1994) terdapat akun hak minoritas atas laba bersih anak perusahaan yang menjadi pengurang dari total laba bersih perusahaan. Hal ini terjadi karena perusahaan menggunakan teori induk perusahaan (parent company theory), Teori ini menyajikan hak kepentingan nonpengendali atas laba bersih dijadikan pengurang untuk total laba perusahaan yang hasilnya merupakan laba yang diterima untuk pemegang saham mayoritas.

Sedangkan dalam laporan laba rugi komprehensif konsolidasian tahun 2012 yang berpedoman pada PSAK 4 (revisi 2009) menyajikan akun tersebut sebagai laba yang diatribusikan untuk kepentingan non pengendali yang disajikan terpisah dari laba yang diatribusikan untuk pemilik entitas induk. Hal ini terjadi karena perusahaan menggunakan teori entitas (entity theory) yang berfokus pada perusahaan sebagai entitas ekonomis terpisah bukan pada hak kepemilikan dari pemegang saham.

Tabel 3

PT TEMPO SCAN PACIFIC TbK DAN ANAK PERUSAHAAN LAPORAN PERUBAHAN EKUITAS KONSOLIDASIAN

TAHUN YANG BERAKHIR PADA 31 DESEMBER 2010 DAN 2012 (Disajikan dalam Rupiah, kecuali dinyatakan lain)

\begin{tabular}{|c|c|c|c|c|c|}
\hline No. & Nama Akun & 2010 & No. & Nama Akun & 2012 \\
\hline & \multicolumn{5}{|l|}{ SALDO 31} \\
\hline & \multirow[t]{3}{*}{ DESEMBER 2008} & & & \multicolumn{2}{|l|}{ SALDO 31 DESEMBER 2010} \\
\hline & & & 1. & Penambahan kepentingan & \\
\hline & & & & Non-pengendali & 2.250 .000 .000 \\
\hline & \multicolumn{5}{|l|}{ SALDO 31} \\
\hline & \multirow[t]{3}{*}{ DESEMBER 2009} & & & \multicolumn{2}{|l|}{ SALDO 31 DESEMBER 2011} \\
\hline & & & 2. & Pelepasan kepentingan & \\
\hline & & & & Non-pengendali & $(15.589 .095 .430)$ \\
\hline & \multicolumn{5}{|l|}{ SALDO 31} \\
\hline & DESEMBER 2010 & & & SALDO 31 DESEMBER 2012 & \\
\hline
\end{tabular}

- Laporan perubahan ekuitas konsolidasian tahun 2010 yang berpedoman pada PSAK 4 (revisi 1994) dengan tahun 2012 yang berpedoman pada PSAK 4 (revisi 2009) hanya terdapat perbedaan pada disajikannya akun pelesapasan kepentingan nonpengendali entitas anak dalam laporan perubahan ekuitas konsolidasian tahun 2012 sedangkan pada laporan perubahan ekuitas konsolidasian tahun 2010 tidak disajikan. Akun tersebut menjadi pengurang terhadap total saldo kepentingan nonpengendali yang terdapat dalam laporan posisi keuangan konsolidasian, dimana akun kepentingan nonpengendali tersebut menjadi akun penambah dari total ekuitas. Apabila saldo akun kepentingan nonpengendali tersebut berkurang, maka akan berkurang pula total ekuitas dalam laporan posisi keuangan. 
Menurunnya totas ekuitas akan berdampak pada Return on Equity (ROE) yang memiliki rumus perhitungan :

$$
\text { Return on Equity }(R O E)=\frac{E A T}{\text { Jumlah Equity }} \times 100 \%
$$

Jika total ekuitas yang menjadi pembagi dalam rumus di atas menurun, maka persentase yang dihasilkan dari rumus ROE di atas akan meningkat. Jadi dapat diambil kesimpulan bahwa apabila persentase ROE semakin meningkat maka akan berdampak baik, karena perusahaan dianggap telah efektif dalam menggunakan ekuitasnya untuk menghasilkan laba.

Tabel 4

PT TEMPO SCAN PACIFIC TbK DAN ANAK PERUSAHAAN

LAPORAN ARUS KAS KONSOLIDASIAN

TAHUN YANG BERAKHIR PADA 31 DESEMBER 2010 DAN 2012

(Disajikan dalam Rupiah, kecuali dinyatakan lain)

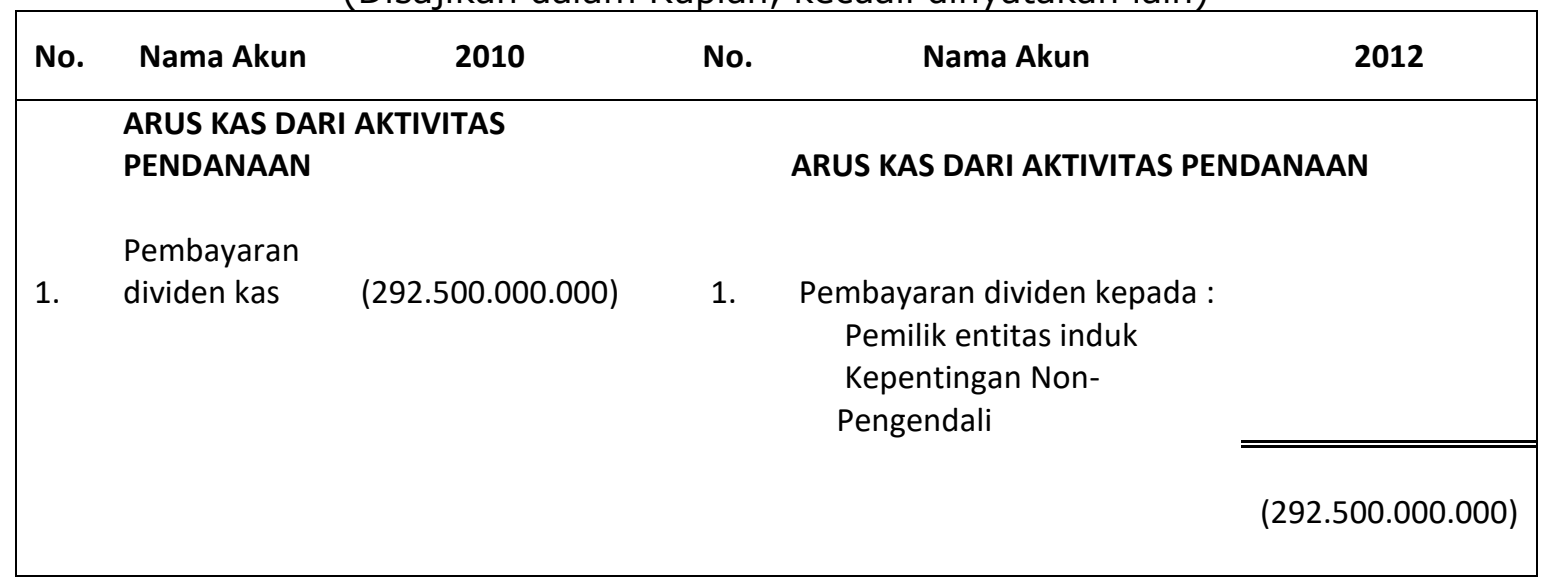

- Laporan arus kas konsolidasian tahun 2010 yang berpedoman pada PSAK 4 (revisi 1994) dan laporan arus kas konsolidasian tahun 2012 yang berpedoman pada PSAK 4 (revisi 2009) hanya terdapat pada penyajian pembayan dividen yang sebelumnya disajikan tidak terpisah antara dividen yang dibayarkan untuk pemilik entitas induk dan untuk kepentingan nonpengendali, kemudian pada laporan arus kas tahun 2012 disajikan terpisah antara pemilik entitas induk dan kepentingan nonpengendali. Hal ini terkait juga dengan teori yang digunakan untuk laporan keuangan konsolidasian tahun 2010 adanya parent company theory atau teori induk perusahaan, sedangkan untuk laporan keuangan konsolidasian tahun 2012 adalah entity theory atau teori entitas seperti yang sudah dibahas sebelumnya.

\section{KESIMPULAN}

Secara keseluruhan laporan keuangan konsolidasian PT Tempo scan Pacific Tbk tahun 2010 yang sesuai dengan PSAK 4 (revisi 1994) dan tahun 2012 yang sesuai dengan PSAK 4 (revisi 2009) sudah disajikan dengan benar dan diungkapkan secara jelas kecuali untuk beberapa bagian yang belum diungkapkan perusahaan karena tidak sesuai dengan kebijakan perusahaan itu sendiri. Karena tidak semua poin di dalam PSAK 4 dapat diterapkan terhadap semua perusahaan. Hal tersebut harus disesuaikan dengan kebijakan masing-masing perusahaan yang bersangkutan. 
Serta dari analisis perbedaan yang ada karena perubahan yang terjadi akibat konvergensi IFRS terhadap laporan keuangan konsolidasian tahun 2010 yang berpedoman pada PSAK 4 (revisi 1994) dan tahun 2012 yang berpedoman pada PSAK 4 (revisi 2009), secara keseluruhan perbedaan tersebut memberikan dampak yang positif atau dengan kata lain perubahan tersebut menguntungkan perusahaan kecuali perubahan yang terjadi pada akun kepentingan nonpengendali yang pada tahun 2010 disajikan sebagai hak minoritas atas aset bersih anak perusahaan pada laporan posisi keuangan konsolidasian di antara kewajiban dan ekuitas, kemudian menjadi akun kepentingan nonpengendali yang menjadi bagian dari ekuitas terpisah dari ekuitas pemilik entitas induk yang secara otomatis akan menambah total dari ekuitas perusahaan. Meningkatnya total dari ekuitas tersebut akan berdampak bagi menurunnya Return on Equity (ROE) yang berdampak tidak baik bagi perusahaan.

\section{SARAN}

Untuk selanjutnya perusahaan seharusnya menjelaskan poin-poin dalam PSAK 4 yang telah sesuai dengan kebijakan perusahaan tersebut secara lebih rinci di dalam catatan atas laporan keuangan konsolidasiannya. Hal ini agar para pengguna informasi terutama para penyedia dana mendapatkan informasi yang dibutuhkan untuk mengambil keputusan.

Perubahan akibat dari konvergensi IFRS seperti yang sudah penulis teliti secara keseluruhan memberikan dampak yang positif bagi perusahaan kecuali untuk beberapa akun. Perubahan selanjutnya seharusnya akan lebih baik lagi dan memberikan dampak yang lebih positif bagi perusahaan maupun bagi para pengguna laporan keuangan lainnya.

Untuk laporan keuangan konsolidasian tahun 2015 sebaiknya PT Tempo Scan Pacific Tbk mulai menerapkan PSAK 65 (revisi 2013) : Laporan Keuangan Konsolidasian terhadap laporan keuangan konsolidasiannya, karena PSAK 65 (revisi 2013) ini merupakan pengganti untuk PSAK 4 (revisi 2009) : Laporan Keuangan Konsolidasian dan Laporan Keuangan Tersendiri yang sudah efektif pada tanggal 1 Januari 2015.

\section{DAFTAR PUSTAKA}

Baker, Richard E, King, Thomas E. Dan Jeffrey, Cynthia G. 2009. Advance Financial Accounting (An Indonesian Perspective), Salemba Empat, Jakarta.

Baker, Richard E., Valdean C Lembke, Thomas E King and Cynthia G Jeffrey. 2010. Advanced Financial Accounting. Salemba Empat: Jakarta.

Carl S. Warren, James M. Reeve, Philip E. Fess. 2005. Pengantar Akuntansi, Aria Farahmita, Amanugrahani dan Taufik Hendrawan, Edisi 21, 2006, Salemba Empat, Jakarta.

Drebin, Allan R., 2006. Advance Accounting. Edisi 5. Alih Bahasa: Drs. Ak. Freddy Saragih, Drs. Ak. Marianus Sinaga, Suryadi Saat. Penerbit Erlangga, Jakarta.

Dwi Martani. 2012. Kepentingan Nonpengendali: http://staff.blog.ui.ac.id (Diakses 2 Oktober 2014)

Fahuwu Zebua. 2009. Akuntansi Keuangan Lanjutan jilid 1. Edisi 2. Mitra Wacana, Jakarta. 
Floyd A.Beams, Joseph H.Anthony, Robin P.Clement, Suzanne H. Lowensohn Advance Accounting 8th Edition Edisi 2007 PT Indeks Jakarta.

Floyd A. Beams., Joseph H. Anthony., Robin P. Clement., dan Suzanne H. Lowensohn. 2009. Akuntansi Lanjutan Jilid 1. Edisi 9. Erlangga, Jakarta.

Hana Hardian. 2011. IAS 27: http://hanahardian.blogspot.com/2011/05/iasno-27.html. (Diakses 10 Oktober 2014)

http://kyle893.files.wordpress.com 2014. (Diakses 12 Oktober 2014)

Ikatan Akuntan Indonesia. 2009. Standar Akuntansi Keuangan, Salemba Empat, Jakarta.

Juan, Ng Eng., Ersa Tri Wahyuni, 2012. Panduan Praktis Standar Akuntansi Keuangan. Edisi 2, Salemba Empat, Jakarta.

kelascakuntansi2011.blogspot.com (Diakses tanggal 16 Agustus 2015)

Kieso, Donald E., Jerry J. Weygant and Terry D.Warfield, 2011. Intermediate Accounting, John wiley \& Sons, Inc. United States of America.

Sawir, Agnes, 2009. Analisa Kinerja keuangan dan Perencanaan Keuangan Perusahaan, PT. Gramedia Pustaka Utama, Jakarta.

Setiawan, B. (2013). Menganalisa Statistik Bisnis dan Ekonomi dengan SPSS 21. Yogyakarta: CV Andi Offset

Setiawan, B. (2015). Teknik Praktis Analisis Data Penelitian Sosial \& Bisnis dengan SPSS. Yogakarta: CV Andi Offset.

Syafri Harahap, Sofyan, 2009. Analisis Kritis atas Laporan Keuangan. Rajawali Press, PT. Raja grafindo Persada, Jakarta.

Syafri Harahap, Sofyan, 2008. Analisa Kritis atas Laporan Keuangan, PT. Raja Grafindo Persada, Jakarta.

www.ekonomikabisnis.com. (Diakses 24 September 2014) 